\title{
Effects of Photoperiod During the Dry Period on Cellular Immune Function of Dairy Cows
}

\author{
T. L. Auchtung, ${ }^{1}$ J. L. Salak-Johnson, ${ }^{1}$ D. E. Morin, ${ }^{2}$ \\ C. C. Mallard, ${ }^{2}$ and G. E. Dahl ${ }^{1}$ \\ ${ }^{1}$ Department of Animal Sciences and \\ ${ }^{2}$ Department of Veterinary Clinical Medicine, \\ University of Illinois, Urbana 61801
}

\section{ABSTRACT}

Recent studies suggest that exposure of cattle to photoperiod can influence immune function. The objective of this study was to determine whether treatment of cows with short day photoperiod (SDPP; 8 h light: 16 $\mathrm{h}$ darkness) during the dry period alters immune function, relative to cows subjected to a long day photoperiod (LDPP; $16 \mathrm{~h}$ light: $8 \mathrm{~h}$ darkness). Multiparous Holstein cows $(\mathrm{n}=39)$ were dried $62 \mathrm{~d}$ before calving and exposed to photoperiod treatment until parturition; thereafter, cows were exposed to natural photoperiod. General health was monitored weekly during the dry period and cellular immune function was examined monthly during the dry period and at calving. Concentrations of prolactin and cortisol were measured from $10 \mathrm{~d}$ before calving to $2 \mathrm{~d}$ after calving. The periparturient prolactin surge in plasma was greater in LDPP cows (54.6 ng/ $\mathrm{mL})$ than SDPP $(22.4 \mathrm{ng} / \mathrm{mL})$. Relative to LDPP cows, neutrophil chemotaxis and lymphocyte proliferation were enhanced in SDPP cows during the dry period. Neutrophil chemotaxis averaged 142.5 and 178.8 cells/ well during the dry period for LDPP and SDPP, respectively. Lymphocyte proliferation during the dry period averaged 197.6 and $326.5 \%$ for LDPP and SDPP cows, respectively. Physiological characteristics of the cows were not affected by treatment during the dry period. However, differences between treatments were observed within $2 \mathrm{~d}$ of parturition. Potential implications of photoperiod management for cow health and wellbeing merit further investigation.

(Key words: photoperiod, dry period, immune function)

\begin{abstract}
Abbreviation key: C5a $=$ complement $5 \mathrm{a}, \operatorname{Con} \mathbf{A}=$ concanavalin A, LDPP = long day photoperiod, $\mathbf{P R L}=$ prolactin, $\mathbf{P R L}-\mathbf{R}=$ prolactin receptor, $\mathbf{S D P P}=$ short day photoperiod.
\end{abstract}

Received April 7, 2004.

Accepted June 26, 2004.

Corresponding author: Geoffrey E. Dahl; email: gdahl@uiuc.edu.

\section{INTRODUCTION}

Photoperiod management is of interest to the dairy industry because it is a safe, noninvasive, and effective method to enhance milk production that can be used throughout the lactation cycle. Long day photoperiod (LDPP; $16 \mathrm{~h}$ light: $8 \mathrm{~h}$ darkness) during lactation increases milk yield an average of $2.0 \mathrm{~kg} / \mathrm{d}$ per cow compared with natural photoperiod (Dahl et al., 2000). In contrast, short day photoperiod (SDPP; $8 \mathrm{~h}$ light: $16 \mathrm{~h}$ darkness) during the dry period yields increased milk production in the subsequent lactation as much as 3.2 $\mathrm{kg} / \mathrm{d}$ compared with cows treated with LDPP when dry (Miller et al., 2000). Thus, appropriate manipulation of photoperiod can dramatically improve the performance of dairy cows.

In addition to well-described effects on reproduction and lactation, there is growing evidence that photoperiod affects immune function in many species (Nelson et al., 1995). In rodents, studies have shown relative beneficial effects of SDPP over LDPP that include increased lymphocyte proliferation and natural killer cell cytotoxicity (Yellon et al., 1999) as well as attenuation of infection (Bilbo et al., 2002a). Recently, our laboratory has observed enhanced cellular immune function in steers maintained on SDPP compared with LDPP (Auchtung et al., 2003a). Managing photoperiod to positively influence the immune system of dairy cows, particularly in the periparturient period, could have a substantial impact on cow health and well-being.

The first objective of the present study was to determine the effect of photoperiod management during the dry period on basic aspects of cellular immune function and physiological characteristics during the dry and periparturient periods. The second objective of the study was to examine the effect of photoperiod on prolactin (PRL) and cortisol during the periparturient period. Effects of photoperiod on milk yield, DMI, and PRL receptors are reported in Rius et al. (2003).

\section{MATERIALS AND METHODS}

\section{Experimental Design}

Multiparous Holstein cows $(\mathrm{n}=39)$ were randomly assigned to $\operatorname{SDPP}(\mathrm{n}=19)$ or $\operatorname{LDPP}(\mathrm{n}=20)$, balanced by 
previous milk production and calving date. Treatments began at dryoff during January and February 2002, which averaged $62 \pm 3 \mathrm{~d}$ before calving. The dryoff procedure consisted of infusion of all 4 quarters of the mammary gland with antibiotic (cephapirin benzathine, Fort Dodge, IA) and an initial vaccination (first of 3 vaccinations; dryoff, $30 \mathrm{~d}$ dry, and within $48 \mathrm{~h}$ postpartum) against gram-negative core antigens, Escherichia coli J5 (Upjohn J-5 Bacterin, Pfizer, Kalamazoo, MI). Following parturition, cows were returned to a natural photoperiod (April to June 2002). During the dry period, cows were housed in an enclosed, mechanically ventilated barn with controlled light exposure, with minimal external light. Lighting was provided by metal halide lights at approximately $450 \pm 10 \mathrm{~lx}$ at eye level of the cows. Lights were turned on at $0800 \mathrm{~h}$ and off at 1600 $\mathrm{h}$ and $2400 \mathrm{~h}$ for SDPP and LDPP treatments, respectively. Sand-bedded free-stalls were used until just before calving, when cows were moved to individual strawbedded box stalls. Blood was collected from the tail vessel into Vacutainer tubes containing EDTA (Becton Dickinson and Co., Franklin Lakes, NJ). Samples were collected at, $30 \mathrm{~d}$ after dryoff, 2 wk before expected calving date, within $12 \mathrm{~h}$ of calving, and $2 \mathrm{~d}$ after calving. Total white blood cell concentrations were determined by flow cytometry (Abbott Cell Dyn 3500, Abbott Park, IL) and differential leukocyte concentrations were determined by visual examination of Giemsastained blood smears.

Milk and udder characteristics were observed at dryoff, in addition to general health variables. A complete physical examination was performed on each cow just before dryoff. Health was assessed once weekly during the dry period by evaluating the following parameters: attitude (alert, depressed); rectal temperature (by glass thermometer); rumen fill (by ballottement); urine ketone concentration (by dipstick test; Ketostick, Bayer, West Haven, CT); respiratory effort (normal, increased); oculonasal discharge (present, absent); cough (present, absent); fecal score; mammary gland size (normal, large, small); mammary gland consistency (normal, firm, edematous); behavior (normal, abnormal); and gait and stance (normal, abnormal). A complete physical examination was performed at calving and daily for $10 \mathrm{~d}$ thereafter. As well as the above variables, the complete physical examination included ability to rise (normal, with difficulty, recumbent); heart rate and rhythm (by auscultation for $1 \mathrm{~min}$ ); respiratory rate (by observation for $1 \mathrm{~min}$ ), breath sounds (by auscultation); rumen contraction rate (by auscultation for $2 \mathrm{~min}$ ); abdominal pings (by simultaneous auscultation and percussion); subjective temperature of extremities (by palpation of ears and fetlocks); mucous membrane color; capillary refill time (assessed at vulva); odor (none, foul) of vaginal discharge; fetal membranes (present, absent); skin tent duration (on lateral neck); eyeball recession into the orbit; and subjective evidence of blood in the feces (black feces or fresh blood). Mammary glands were subjectively evaluated for size, color, consistency, temperature, and pain; teats were evaluated for lesions. The viscosity, color, and consistency of mammary secretions were recorded. At dryoff, calving, and $10 \mathrm{~d}$ after calving, cows were evaluated for abdominal pain by observing response to pinching of the withers (ventroflexion, no ventroflexion, grunting, no grunting) and peripheral lymph nodes were palpated (normal, subjectively enlarged). Body condition score was assessed at dryoff, calving, and $10 \mathrm{~d}$ after calving. All examinations were performed by a veterinarian, veterinary research specialist, or supervised veterinary student, all of whom were masked to treatment group.

Cows were fed individually using a Calan feeding system with intake and refusals recorded daily. Dry matter intake was monitored during the dry period and for $21 \mathrm{~d}$ postcalving. Cows were milked twice daily; milk production and composition was monitored for the first 16 wk of lactation. Dry matter intake, milk production, and milk composition results are reported in Rius et al. (2003). Quarter foremilk samples were collected weekly for the first month after calving and then monthly for the duration of the study for diagnostic bacteriology and SCC determination (Dairy Laboratory Services, Dubuque, IA). Incidence of mastitis and IMI for cows in this experiment are reported in Auchtung et al. (2003b). All animal procedures were approved by the University of Illinois Institutional Animal Care and Use Committee.

\section{Blood Sampling and Hormone Assays}

Blood (10 mL) was collected via jugular venipuncture of all cows restrained individually in a chute, using sterile Vacutainer tubes containing sodium heparin (Becton Dickinson and Co.). Collection occurred twice daily, between 0830 and $0930 \mathrm{~h}$ and between 2030 and $2130 \mathrm{~h}$, starting $5 \mathrm{~d}$ before expected calving date and continuing until $2 \mathrm{~d}$ after calving. Samples were chilled on ice immediately after collection. Within $2 \mathrm{~h}$ of collection, plasma for hormone determination was obtained from whole blood following centrifugation $(1850 \times g, 20$ $\min , 4^{\circ} \mathrm{C}$ ) and stored at $-20^{\circ} \mathrm{C}$ until assayed.

Concentrations of plasma PRL were determined by radioimmunoassay as described by Miller et al. (1999). Mean intra- and interassay coefficients of variation (2 assays) were 7.6 and $12.8 \%$, respectively. Assay sensitivity averaged $0.97 \mathrm{ng} / \mathrm{mL}$. Heparinized plasma samples were assayed for cortisol using a Coat-A-Count cortisol kit (Diagnostic Products Corporation, Los 
Angeles, CA). Assay sensitivity averaged $2.4 \mathrm{ng} / \mathrm{mL}$. Cortisol concentrations were determined in samples collected between 0830 and $1030 \mathrm{~h}$ biweekly during the dry period and between 0830 and $0930 \mathrm{~h}$ from $10 \mathrm{~d}$ before calving, continuing to $2 \mathrm{~d}$ postpartum.

\section{Lymphocyte Proliferation Assay}

Bovine peripheral blood mononuclear cells were isolated from blood samples collected biweekly during the dry period and at $2 \mathrm{~d}$ postcalving between 0830 and $1030 \mathrm{~h}$ from a subset of cows $(\mathrm{n}=12 ; 6$ from each treatment) on sodium heparin by density gradient centrifugation through Histopaque-1077 (density: 1.077; Sigma Chemical Co., St. Louis, MO). The cells were washed twice in RPMI-1640 (Sigma), resuspended, and the cell concentration adjusted to $5 \times 10^{6}$ cells $/ \mathrm{mL}$ (Morrow-Tesch et al., 1994) in RPMI supplemented with $10 \%$ fetal bovine serum (Sigma) and $50 \mu \mathrm{g} / \mathrm{mL}$ gentamicin (Sigma). Diluted lymphocytes $(100 \mu \mathrm{L})$ were added in triplicate to 96 -well, flat-bottom sterile plates. Concanavalin A (ConA, Sigma) and pokeweed mitogen (Sigma) were added $(100 \mu \mathrm{L})$ in triplicate at various doses (pokeweed mitogen: 0, 0.1, 1, and $10 \mu \mathrm{g} / \mathrm{mL}$; ConA: $0,0.2,2$, and $20 \mu \mathrm{g} / \mathrm{mL})$. Each plate contained only one mitogen to avoid cross-contamination. Cells (total volume of $200 \mu \mathrm{L}$ ) were then incubated for $48 \mathrm{~h}$ at $37^{\circ} \mathrm{C}$ in $5 \% \mathrm{CO}_{2}$. Approximately $24 \mathrm{~h}$ later, $20 \mu \mathrm{L}$ of (3-[4,5dimethylthiazol-2-yl]-2,5-diphenyltetrazolium bromide was added to each well (optimum concentration of 1 $\mathrm{mg} / \mathrm{mL}$ in RPMI) and the cells were incubated for an additional $4 \mathrm{~h}$. Following incubation, $100 \mu \mathrm{L}$ of acidic isopropanol was added to each well, and the contents were mixed by repeated pipetting. The optical density of each well was measured at $600 \mathrm{~nm}$ within $1 \mathrm{~h}$. Proliferation is expressed as the stimulation index, which is the optical density of the treated wells/optical density of the unstimulated control wells (cells receiving no mitogen).

\section{Neutrophil Chemotaxis Assay}

Blood ( $7 \mathrm{~mL}$ ) for neutrophil isolation was collected at the same time as the samples collected for lymphocyte proliferation (above), using Vacutainer tubes containing EDTA. After centrifugation $(1850 \times g, 20 \mathrm{~min}$, $4^{\circ} \mathrm{C}$ ), the plasma layer, buffy coat, and approximately one-fourth of the red cell layer were removed. Cold water $(10 \mathrm{~mL})$ was added to the remaining cell layer and mixed thoroughly. Isotonicity was restored after $1 \mathrm{~min}$ by adding $5 \mathrm{~mL}$ of $3 \times$ PBS. The cells were centrifuged for $10 \mathrm{~min}$ at $475 \times \mathrm{g}$. The supernatant was poured off and red blood cell lysis was repeated as needed. Cell pellets were resuspended in $2 \mathrm{~mL}$ of PBS and neutrophil numbers determined using a Coulter counter (Coulter Electronics, Miami, FL). The chemoattractants used in these experiments were human IL-8 $(100 \mathrm{ng} / \mathrm{mL}$; Sigma) and recombinant human complement 5a (C5a; $10^{-8} M$; Sigma). Approximately $30 \mu \mathrm{L}$ of the chemoattractant or control medium was placed in each well of the bottom chamber of the chemotaxis chamber. Before loading the top chamber with neutrophils, the chamber was equilibrated in an incubator for 10 to $15 \mathrm{~min}$ at $5 \% \mathrm{CO}_{2}$ and $37^{\circ} \mathrm{C}$. During equilibration, the cell concentrations were adjusted using RPMI-1640 medium to a concentration of $3 \times 10^{6}$ cells $/ \mathrm{mL}$. The adjusted cell solution was added to the top chamber at $50 \mu \mathrm{L} /$ well and the chemotaxis chamber was incubated for $1 \mathrm{~h}$. Following incubation, the noncell side of the filter was wiped with $3 \times$ PBS and then dried. The cell side was then dipped in methanol 8 times and dried. Finally, the filter was stained with Diff-Quick (Fisher Scientific, Pittsburgh, PA), placed on a microscope slide, and allowed to dry. Five fields per well were counted at $40 \times$ magnification to determine the number of neutrophils that migrated in response to either chemoattractant or medium.

\section{Statistical Analyses}

Statistical analyses were performed using the SAS System version 8.2 (SAS Inst., Inc., Cary, NC). All data were normally distributed. A mixed model was used to analyze repeated measures data, specifically comparing variables between LDPP- and SDPP-treated animals and across time. Ambient temperature and pretreatment hormone values were used as covariates in the model analyzing PRL concentrations. Treatment least squares means and standard errors of the difference (SED) are reported.

\section{RESULTS}

\section{General Health}

During the dry period, cows were monitored weekly for general health; Table 1 summarizes selected variables. Photoperiod did not affect these variables during the dry period. Over the course of the experiment, there were no differences in urine ketones, udder characteristics, dehydration, lymph node normality, or consistency of mucous membranes. However, differences in heart rate, respiratory rate, and rectal temperature were observed postcalving, with SDPP cows having greater values relative to LDPP cows (Table 1).

\section{Prolactin and Cortisol Concentrations}

The periparturient PRL surge was greater in LDPP cows $(P<0.05)$ than SDPP cows (Figure 1$)$. Plasma 
Table 1. Selected physiological characteristics of cows maintained on long (LDPP) or short (SDPP) day photoperiod during the dry period. Variables were measured before treatments at dryoff and at $2 \mathrm{~d}$ after parturition.

\begin{tabular}{lccl}
\hline Variable & LDPP & SDPP & SED \\
\hline Dryoff & & & \\
Heart rate (beats/min) & 84.9 & 82.9 & 7.4 \\
Respiratory rate (breaths/min) & 28.6 & 34.2 & 5.5 \\
Rectal temperature ( ${ }^{\circ}$ ) & 101.5 & 96.6 & 5.1 \\
Rumen contraction rate (per 2 min) & 1.8 & 2.3 & 0.56 \\
Body condition score (1 to 5) & 3.48 & 3.41 & 0.12 \\
Postcalving & & & \\
Heart rate (beats/min) & $82.8^{\mathrm{a}}$ & $85.1^{\mathrm{b}}$ & 1.4 \\
Respiratory rate (breaths/min) & $39.1^{\mathrm{a}}$ & $46.8^{\mathrm{b}}$ & 1.3 \\
Rectal temperature $\left({ }^{\circ} \mathrm{F}\right)$ & $102.1^{\mathrm{a}}$ & $102.5^{\mathrm{b}}$ & 0.1 \\
Rumen contraction rate (per 2 min) & 2.8 & 2.7 & 0.13 \\
Body condition score (1 to 5) & 3.22 & 3.32 & 0.10 \\
\hline
\end{tabular}

${ }^{a, b}$ Within a row, values with different superscripts are different at $P<0.05$. Values are presented as least squares means $(\mathrm{n}=39)$.

PRL concentrations peaked at 54.6 and $22.4 \mathrm{ng} / \mathrm{mL}$ for LDPP and SDPP cows, respectively. Plasma cortisol concentrations during the dry period were not different $(P=0.27)$ between treatment groups with concentrations averaging 16.8 and $17.9 \mathrm{ng} / \mathrm{mL}(\mathrm{SED}=1.4)$, for LDPP and SDPP cows, respectively. Concentrations of cortisol also did not differ during the $10 \mathrm{~d}$ before and $2 \mathrm{~d}$ after calving, with LDPP cows averaging $19.1 \mathrm{ng} /$ $\mathrm{mL}$ and SDPP cows averaging $16.0 \mathrm{ng} / \mathrm{mL}(\mathrm{SED}=3.6)$.

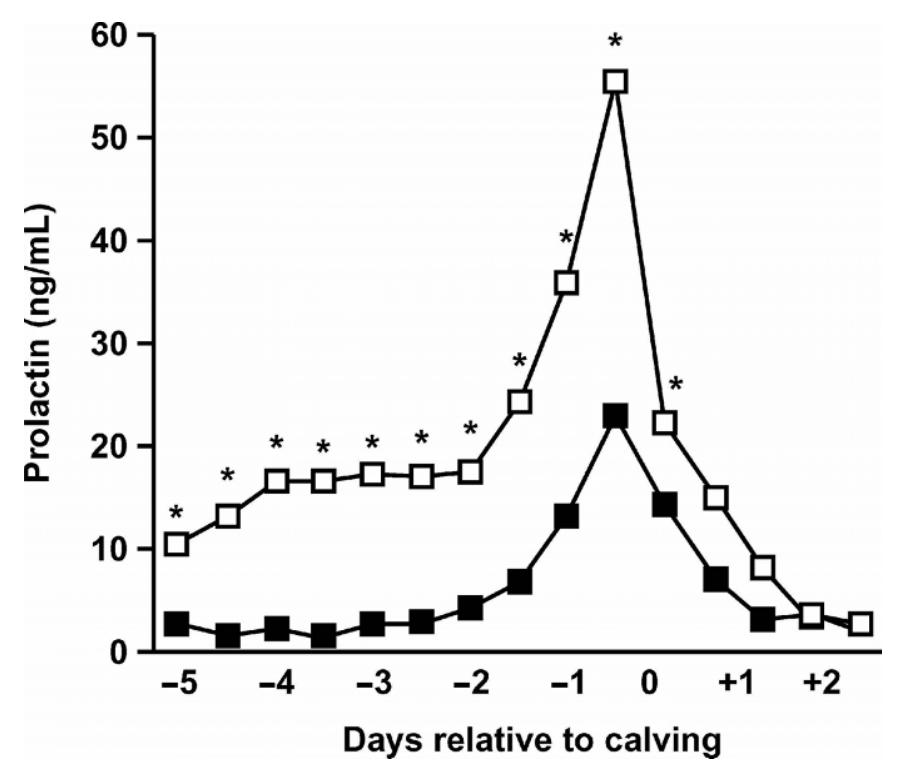

Figure 1. Average concentrations $(\mathrm{ng} / \mathrm{mL})$ of prolactin in plasma during the periparturient period of cows on different photoperiods. Samples were collected via tail venipuncture at 12 -h intervals. Solid squares $(\square)$ represent short day photoperiod treatment (SDPP; $\mathrm{n}=$ 10 ); open squares $(\square)$ represent long day photoperiod treatment $(\mathrm{LDPP} ; \mathrm{n}=10)$. Standard errors of the difference $=4.5 \mathrm{ng} / \mathrm{mL}\left(^{*}=\right.$ $P<0.05$ between groups).

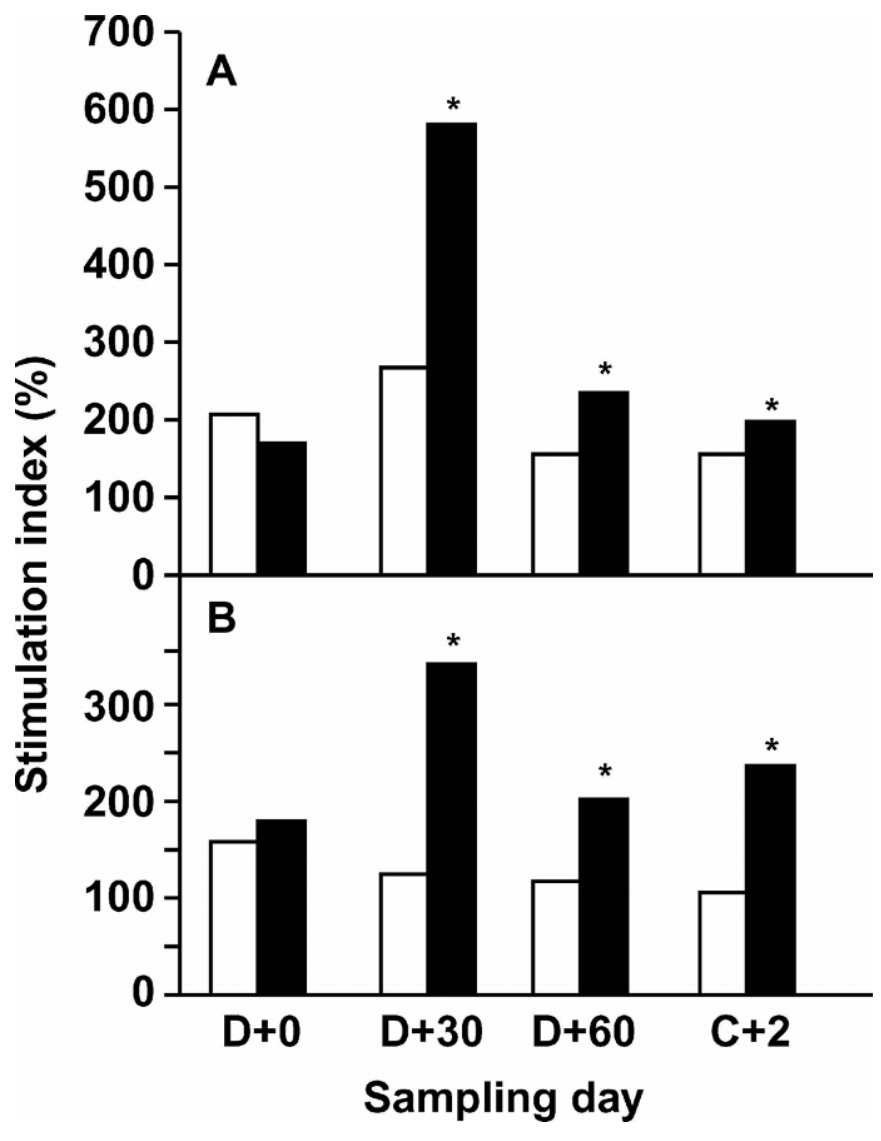

Figure 2. Effect of photoperiod management during the dry period on lymphocyte proliferation of multiparous cows $(n=12)$. Proliferation of lymphocytes in response to A) concanavalin A and B) pokeweed mitogen. Dryoff $=\mathrm{D}$; calving $=\mathrm{C}$ with respect to day of blood sampling. Solid bars $(\mathbf{\square})$ represent short day photoperiod treatment (SDPP; $\mathrm{n}=$ 6 ); open bars $(\square)$ represent long day photoperiod treatment (LDPP; $\mathrm{n}=6$ ). Values represent cells that proliferated in response to the mitogen as a percentage of unstimulated controls $(*=P<0.05)$. Standard errors of the difference $=39.4 \%($ Panel A) and $56.1 \%$ (Panel B).

\section{Cellular Immune Function}

Whole white blood counts performed at dryoff showed no difference between treatments in any of the blood cell types (data not shown). At calving however, there was an increase in immature neutrophils as parturition approached in both treatment groups. There was no difference between treatment groups for the remainder of the cell type categories. Lymphocyte proliferation in response to ConA (Figure 2; Panel A) and pokeweed mitogen (Figure 2; Panel B) was greater in SDPP cows compared with LDPP cows within the first month of photoperiod treatment. This response persisted through the dry period and into the first few days of lactation. Neutrophil migration to IL-8 (Figure 3; Panel A) and C5a (Figure 3; Panel B) was also greater in SDPP cows relative to LDPP cows. Although there was 


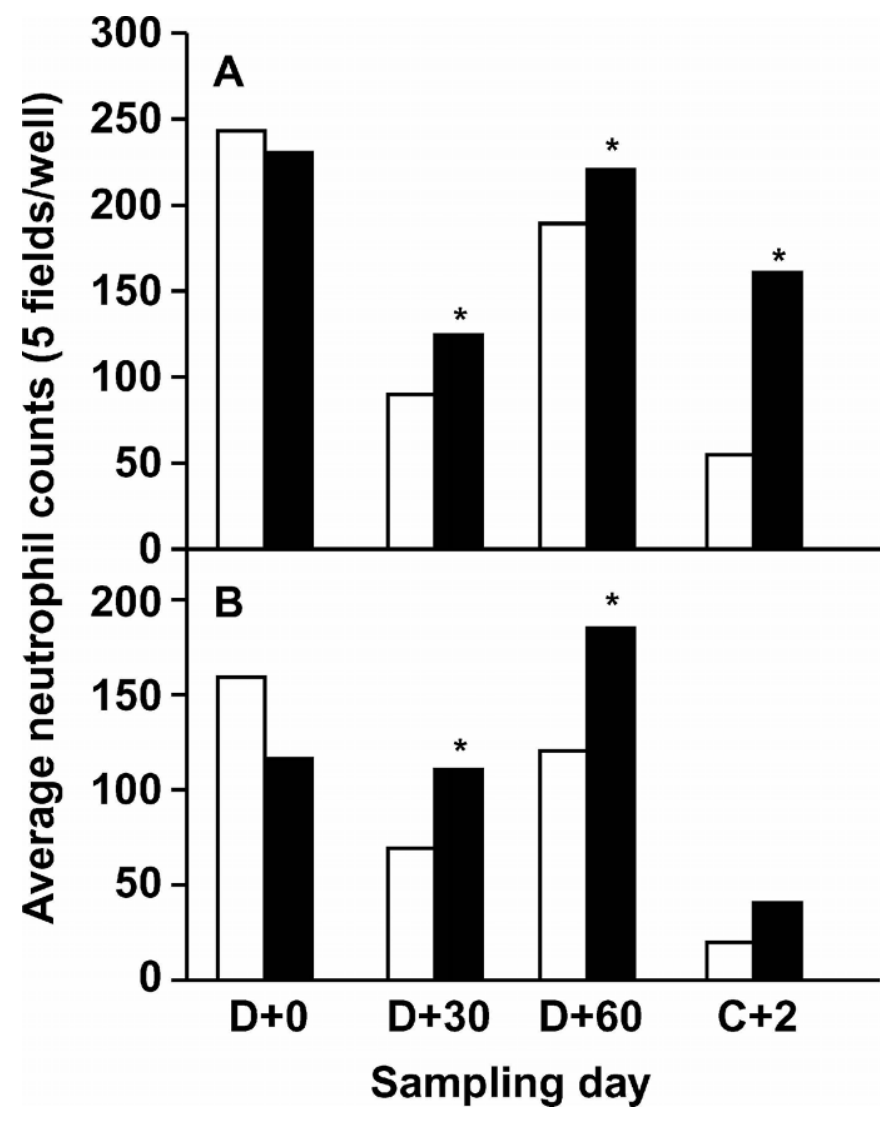

Figure 3. Effect of photoperiod management during the dry period on neutrophil chemotaxis in multiparous cows $(\mathrm{n}=12)$. Neutrophil migration in response to A) interleukin-8 and B) complement C5a. Dryoff $=\mathrm{D}$; calving $=\mathrm{C}$ with respect to day of blood sampling. Solid bars (ם) represent short day photoperiod treatment (SDPP; $\mathrm{n}=6$ ); open bars $(\square)$ represent long day photoperiod treatment (LDPP; $\mathrm{n}=$ 6 ). Values represent the average number of neutrophils that migrated in response to the specific chemoattractant, averaged over 5 fields per well $(*=P<0.05)$. Standard errors of the difference $=43.7$ (Panel A) and 38.3 (Panel B).

no difference in chemotaxis when the cows were dried off, the increase in directed neutrophil migration in the SDPP cows continued during the dry period and through parturition (Figure 3).

\section{DISCUSSION}

In this study, we confirmed that the periparturient PRL surge is affected by photoperiod management in the dry period. These results are consistent with previous studies (Newbold et al., 1991; Miller et al., 2000) of cows treated with SDPP or LDPP when dry. No change was observed between the treatments in the temporal characteristics of the PRL surge, however LDPP cows had higher peak and prepartum concentrations of PRL than SDPP cows. After calving, all cows were moved to a natural photoperiod environment and therefore their PRL concentrations rapidly became similar. These observations reinforce the concept that extending the photoperiod increases circulating PRL. However, PRL sensitivity, as measured by PRL receptor (PRL-R) mRNA expression, has an inverse response to extended photoperiod (Auchtung et al., 2003a).

Photoperiod had no effect on cortisol in dry cows, as observed previously in lactating cows (Peters et al., 1981) and heifers (Zinn et al., 1986). This is of interest with regard to changes observed in immune function as such changes are frequently associated with fluctuations in glucocorticoids (Mallard et al., 1998). Indeed, there is evidence in rodents that shifts in glucocorticoids may mediate photoperiodic effects on immune function (Bilbo et al., 2002b). However, the lack of photoperiodic effects on cortisol in the bovine, coupled with our observations regarding PRL sensitivity (Rius et al., 2003) suggest that there may be other endocrine factors influencing the immune system in response to photoperiod. Specifically, PRL-R expression was greater on lymphocytes of SDPP cows relative to LDPP cows, and that increased PRL sensitivity is associated with higher immune competence.

In general, physiological characteristics did not differ between treatment groups during the dry period. After calving however, SDPP cows had elevated heart rate, respiratory rate, and rectal temperature. Cows treated with SDPP when dry may have a more rapid response to physiological challenges, such as those at parturition, and thus be better able to adapt and modify their immune responses. For example, we have observed similar rapid responses when cows treated with short day photoperiod during the dry period were challenged with Streptococcus uberis during the first few days of lactation (Morin et al., 2003). Further investigations with more animals are needed to differentiate specific treatment effects on general physiology and health, particularly during periods of stress and reduced immune competence, such as parturition.

Cows exposed to SDPP during the dry period increased lymphocyte proliferation and neutrophil chemotaxis during the dry and postparturient periods relative to LDPP in the present study. These results are consistent with previous observations in cattle (Auchtung et al., 2003a) as well as in hamsters (Yellon et al., 1999; Zhou et al., 2002) exposed to different photoperiods. The overall decrease in lymphocyte proliferation observed as the dry period progressed has been seen in other studies (Kehrli et al., 1989; Asai et al., 1998). Increased lymphocyte proliferation in response to mitogenic stimulation is an index of cellular metabolic activity and may aid in identification and eventual elimination of infectious agents associated with mastitis (Naghata et al., 1987; Park et al., 1993). Indeed, there is 
an inverse relationship between neutrophil chemotaxis and susceptibility to mastitis (Sordillo and Streicher, 2002). The preliminary indication from the present study is that SDPP treatment of the dry cow may have a protective effect on the mammary gland during the periparturient period and into the next lactation. However, confirmation with a larger number of animals is needed. Interestingly, melatonin, which is increased during an increased duration of darkness such as during SDPP, may be protective against mammary cell damage during mastitic infections (Boulanger et al., 2002). Additional investigations of neutrophil function with regard to photoperiod treatment will assist in determining the ultimate endocrine mechanism of photoperiod manipulation on mammary defense.

Bilbo et al. (2002b) observed increased numbers of circulating T cells and leukocyte trafficking in Siberian hamsters under short daily photoperiod. Analysis of the different populations of immune cells showed no difference among the treatment groups in this study. It is important to point out, however, that we did not differentiate the classes of lymphocytes and that may be beneficial, as there is evidence that the different classes are affected as the cow goes through the periparturient period and differences in lymphocyte populations may influence mastitis susceptibility (Yamaguchi et al., 1999; Leitner et al., 2003).

This is the first report showing the potential immune benefits of photoperiod treatment during the dry period of dairy cows. The photoperiodic effects on cellular immune function observed in this study are similar to those of our previous study in Holstein steers (Auchtung et al., 2003a). Data from that study as well as other studies in our laboratory using exogenous PRL in vivo and in vitro suggest that the mediator of changes in immune response with changes in photoperiod is the sensitivity of the animals to PRL. Expression of PRL-R mRNA is inversely related to PRL when cows are subjected to photoperiod management, whereby LDPPtreated animals have increased PRL concentrations and decreased PRL-R expression compared with animals exposed to SDPP (Rius et al., 2003). Of interest, sensitivity to PRL may also be a mediator of the observed changes in milk production in photoperiodically managed cows (Rius et al., 2003). Thus, photoperiodic manipulation during the dry period may enhance production and health through a similar mechanism, namely PRL sensitivity.

\section{CONCLUSIONS}

Short day photoperiod during the dry period has a positive impact on the immune status of dairy cows, relative to long day photoperiod. Neutrophil chemotaxis and lymphocyte proliferation increased under short days during the dry and periparturient periods relative to long days. Photoperiod management during the dry period has potential benefit for the dairy industry, not only with regard to milk production, but also to the overall health of individual cows. Additional research is needed to identify the optimal conditions, such as length of photoperiod treatment and number of hours of darkness, required to elicit a beneficial immune response to photoperiod management during the dry period.

\section{ACKNOWLEDGMENTS}

The authors wish to thank Paul Kendall, Agustin Rius, Brent Pollard, Ryan Graves, and Jennifer Dauderman for their assistance in animal handling and blood collection. Prolactin antisera were provided by A. F. Parlow. This research was supported by grants to G. E. Dahl from the Illinois Council on Food and Agricultural Research (project \#02I-078-3) and US-Israel Binational Agricultural Research and Development Fund (project \#US-3201-01).

\section{REFERENCES}

Asai, K., K. Kai, H. Rikiishi, S. Sugawara, Y. Maruyama, T. Yamaguchi, M. Ohta, and K. Kumagai. 1998. Variation in CD4+ T and CD8+ T lymphocyte subpopulations in bovine mammary gland secretions during lactating and non-lactating periods. Vet. Immunol. Immunopathol. 65:51-61.

Auchtung, T. L., P. E. Kendall, J. L. Salak-Johnson, T. B. McFadden, and G. E. Dahl. 2003a. Effects of photoperiod and bromocriptine on prolactin receptor mRNA expression in bovine liver, mammary gland, and peripheral blood lymphocytes. J. Endocrinol. 179:347-356.

Auchtung, T. L., D. E. Morin, C. C. Mallard, and G. E. Dahl. 2003b. Photoperiod manipulation during the dry period: Effects on general health and mastitis occurrence. Pages 278-279 in Proc. 42nd Ann. Natl. Mast. Mtg., Fort Worth, TX. Natl. Mast. Counc., Madison, WI.

Bilbo, S. D., F. S. Dhabhar, K. Viswanathan, A. Saul, S. M. Yellon, and R. J. Nelson. 2002b. Short day lengths augment stress-induced leukocyte trafficking and stress-induced enhancement of skin immune function. Proc. Natl. Acad. Sci. USA 99:4067-4072.

Bilbo, S. D., D. L. Drazen, N. Quan, L. He, and R. J. Nelson. 2002a. Short day lengths attenuate the symptoms of infection in Siberian hamsters. Proc. R. Soc. Lond., B., Biol. Sci. 269:447-454.

Boulanger, V., X. Zhao, and P. Lacasse. 2002. Protective effect of melatonin and catalase in bovine neutrophil-induced model of mammary cell damage. J. Dairy Sci. 85:562-569.

Dahl, G. E., B. A. Buchanan, and H. A. Tucker. 2000. Photoperiodic effects on dairy cattle: A review. J. Dairy Sci. 83:885-893.

Kehrli, M. E., B. J. Nonnecke, and J. A. Roth. 1989. Alterations in bovine peripheral blood lymphocyte function during the peripartum. Am. J. Vet. Res. 50:215-220.

Leitner, G., R. Eligulashvily, O. Krifucks, S. Perl, and A. Saran. 2003. Immune cell differentiation in mammary gland tissues and milk of cows chronically infected with Staphylococcus aureus. J. Vet. Med. B 50:45-52.

Mallard, B. A., J. C. Dekkers, M. J. Ireland, K. E. Leslie, S. Sharif, C. L. Vankampen, L. Wagter, and B. N. Wilkie. 1998. Alteration in immune responsiveness during the peripartum period and its 
ramification on dairy cow and calf health. J. Dairy Sci. 81:585595.

Miller, A. R. E., R. A. Erdman, L. W. Douglass, and G. E. Dahl. 2000. Effects of photoperiodic manipulation during the dry period of dairy cows. J. Dairy Sci. 83:962-967.

Miller, A. R. E., E. P. Stanisiewski, R. A. Erdman, L. W. Douglass, and G. E. Dahl. 1999. Effect of long daily photoperiod and bovine somatotropin (Trobest) on milk yield in cows. J. Dairy Sci. 82:1716-1722.

Morin, D. E., C. C. Mallard, T. L. Auchtung, and G. E. Dahl. 2003. Response to environmentally-induced Streptococcus uberis mastitis in cows exposed to long or short day photoperiod during the dry period. Pages 336-337 in Proc. 42nd Ann. Natl. Mast. Mtg., Fort Worth, TX. Natl. Mast. Counc., Madison, WI.

Morrow-Tesch, J. L., J. J. McGlone, and J. L. Salak-Johnson. 1994. Heat and social stress effects on pig immune measures. J. Anim. Sci. 72:2599-2609.

Naghata, H., H. Noda, and T. Abe. 1987. Changes in blastogenic response of bovine lymphocytes during acute clinical mastitis. Jpn. J. Vet. Sci. 49:1148-1150.

Nelson, R. J., G. E. Demas, S. L. Klein, and L. J. Kriegsfeld. 1995. The influence of season, photoperiod, and pineal melatonin on immune function. J. Pineal Res. 19:149-165.

Newbold, J. A., L. T. Chapin, S. A. Zinn, and H. A. Tucker. 1991. Effects of photoperiod on mammary development and concentration of hormones in serum of pregnant dairy heifers. J. Dairy Sci. 74:100-108.

Park, Y. H., L. K. Fox, M. J. Hamilton, and W. C. Davies. 1993. Suppression of proliferative response of BoCD4+ lymphocytes by activated BoCD8+ T lymphocytes in the mammary gland of cows with Staphylococcus aureus mastitis. Vet. Immunol. Immunopathol. 36:137-151.

Peters, R. R., L. T. Chapin, R. S. Emery, and H. A. Tucker. 1981. Milk yield, feed intake, prolactin, growth hormone, and glucocorticoid response of cows to supplemented light. J. Dairy Sci. 64:16711678.

Rius, A. G., T. L. Auchtung, P. E. Kendall, T. B. McFadden, and G. E. Dahl. 2003. Evidence for shifts in prolactin sensitivity in cows exposed to long or short day photoperiod. J. Dairy Sci. 86(Suppl. 1):T33. (Abstr.)

Sordillo, L. M., and K. L. Streicher. 2002. Mammary gland immunity and mastitis susceptibility. J. Mammary Gland Biol. Neoplasia $7: 135-146$

Yamaguchi, T., M. Hiratsuka, K. Asai, K. Kai, and K. Kumagai. 1999. Differential distribution of T lymphocyte subpopulations in the bovine mammary gland during lactation. J. Dairy Sci. 82:1459-1464.

Yellon, S. M., O. R. Fagoaga, and S. L. Nehlsen-Cannarella. 1999 Influence of photoperiod on immune cell functions in the male Siberian hamster. Am. J. Physiol. 276:R97-R102.

Zhou, S., F. R. A. Cagampang, J. A. Stirland, A. S. I. Loudon, and S. J. Hopkins. 2002. Different photoperiods affect proliferation of lymphocytes but not expression of cellular, humoral, or innate immunity in hamsters. J. Biol. Rhythms 17:392-405.

Zinn, S. A., R. W. Purchas, L. T. Chapin, D. Petitclerc, R. A. Merkel, W. G. Bergen, and H. A. Tucker. 1986. Effects of photoperiod on growth, carcass composition, prolactin, growth hormone, and cortisol in prepubertal and postpubertal Holstein heifers. J. Anim. Sci. 63:1804-1815. 